\title{
Gold Nanoparticle and Poly(arginine) Modified GCE for Simultaneous Determination of Hydroquinone and Catechol
}

\author{
Altın Nanopartikül ve Poli(arjinin) Modifiye Camsı Karbon Elektrot \\ ile Hidrokinon ve Katekolün Eş Zamanlı Tayini
}

\author{
Research Article
}

Gözde Aydoğdu Tı̆̆

Ankara University, Faculty of Science, Department of Chemistry, Ankara, Turkey.

\section{A B S T R AC T}

\begin{abstract}
n this work, a novel electrochemical sensor based on gold nanoparticle (AuNP) and poly(L-arginine) (P(AG)) modified glassy carbon electrode (GCE) (P(AG)/AuNP/GCE) was designed to determine hydroquinone (HQ) and catechol (CC). Scanning electron microscopy (SEM), cyclic voltammetry (CV) and electrochemical impedance spectroscopy (EIS) were utilized to characterize the $P(A G) / A u N P / G C E$. Differential pulse voltammetry (DPV) results revealed that the modified GCE represented high selectivity for the simultaneous determination of $\mathrm{HQ}$ and CC. The linear working ranges of $\mathrm{HQ}$ and CC were in the concentration range of 5.0 to $600.0 \mu \mathrm{mol} \mathrm{\textrm {L } ^ { - 1 }}$ with the detection limits of 1.5 and $1.42 \mu \mathrm{mol} \mathrm{L}^{-1}$, respectively. The prepared sensor is a suitable tool with low cost for the rapid analysis of $\mathrm{HQ}$ and $\mathrm{CC}$ in the real samples with high recoveries.
\end{abstract}

\section{Key Words}

Hydroquinone, catechol, simultaneous, poly(arginine), AuNP.

\section{öz}

u çalışmada, hidrokinon (HQ) ve katekolün (CC) tayini için altın nanopartikül (AuNP) ve poli(L-arjinin) $(P(A G)$ ) modifiye edilmiş camsı karbon elektrot (GCE) (P(AG)/AuNP/GCE) temelli yeni bir elektrokimyasal sensör tasarlandı. Taramalı elektron mikroskobu (SEM), dönüşümlü voltametri (DV) ve elektrokimyasal impedans spektroskopisi (EIS) P(AG)/AuNP/GCE'yi karakterize etmek için kullanıldı. Diferansiyel puls voltametrisi sonuçları modifiye elektrodun hidrokinon ve katekolün eş zamanlı tayini için yüksek duyarlılık ve hassasiyet gösterdi. HQ ve CC'nin doğrusal çalışma aralığı 5.0 ile $600.0 \mu \mathrm{mol} \mathrm{L-1}$ arasında ve gözlenebilme sınırları sırasıyla 1.5 ve $1.42 \mu \mathrm{mol} \mathrm{L}{ }^{-1}$ olarak bulundu. Hazırlanan sensör hidrokinon ve katekolün gerçek örneklerde hızlı analizi için yüksek geri kazanımla düşük maliyetli uygun bir araç olarak önerildi. Hazırlanan sensör, yüksek geri kazanımlarla gerçek numunelerde HQ ve CC'nin hızlı analizi için düşük maliyetli uygun bir araçtır.

\section{Anahtar Kelimeler}

Hidrokinon, katekol, eş zamanlı, poly(arjinin), AuNP.

Article History: Received: May 18, 2017; Revised: Jun 6, 2017; Accepted: Oct 19, 2017; Available Online: Dec 25, 2017. DOI: $10.15671 /$ HJBC.2017.166

Correspondence to: G.A. Tığ, Ankara University, Faculty of Science, Department of Chemistry, Ankara, Turkey. 


\section{INTRODUCTION}

ydroquinone (HQ) and catechol (CC) are two isomers of dihydroxybenzene that are extensively used in cosmetic, dye, antioxidants and pesticides $[1,2]$. These isomers can be easily introduced into environment as pollutants and they are harmful to organisms in their very low concentrations. $\mathrm{HQ}$ and $\mathrm{CC}$ generally coexist in environment since they have similar structure and property. Several methods such as spectrophotometry [3], chromatography [4], fluorescence [5] and various electrochemical methods [6-8] have been preferred to detect $\mathrm{HQ}$ and $\mathrm{CC}$ simultaneously. Among them, electrochemical techniques have several advantages such as fast response, high selectivity, sensitivity and low cost. In the case of electrochemical analysis of $\mathrm{HQ}$ and $\mathrm{CC}$ their redox peaks can overlap because they have the same electroactive phenolic groups. Thus, these two isomers can be hardly resolved at the surface of unmodified electrodes. Therefore, composite electrodes which differentiate between $\mathrm{HQ}$ and $\mathrm{CC}$ were used as excellent resolving devices. Recently, poly(amino acids) are widely preferred to combine with nanoparticles to form a novel conducting composite for sensor applications. The use of poly(amino acids) have attracted great attention due to their various properties such as low-cost, easy preparation, functional groups and conductivity $[9,10]$. The poly amino acid-modified electrodes were extensively used for the determination of various substances such as pharmaceutical drugs [11-13]. Among these, poly (L-arginine) $(P(A G))$ as a basic amino acid has three amino groups and it can be electrostatically interact with negative groups of different molecules $[14,15]$. Gold nanoparticles have attracted more attention for the construction of modified electrodes due to the advantages in terms of large surface area, biocompatibility and conductivity $[16,17]$.

Herein, a simple and cost-effective electrodeposition technique to construct the AuNP and $P(A G)$ modified GCE (P(AG)/AuNP/GCE) for the simultaneous determination of $H Q$ and $C C$ was reported. The prepared sensor showed high sensitivity for the analysis of $\mathrm{HQ}$ and $\mathrm{CC}$. In addition, the $P(A G) / A u N P / G C E$ showed excellent stability and applicability for the $\mathrm{HQ}$ and $\mathrm{CC}$.

\section{MATERIALS and METHODS}

\section{Materials}

L-Arginine, potassium chloride, $\mathrm{HQ}, \mathrm{CC}$, citric acid, $\mathrm{MgCl}_{2}, \mathrm{NaCl}, \mathrm{KCl}, \mathrm{Na}_{2} \mathrm{HPO}_{4} \cdot 7 \mathrm{H}_{2} \mathrm{O}$ and $\mathrm{NaH}_{2} \mathrm{PO}_{4} \cdot 2 \mathrm{H}_{2} \mathrm{O}$ were purchased from Sigma. UA, urea, glucose and L-cysteine were supplied by Fluka. Hydrogen tetrachloroaurate (III) trihydrate $\left(\mathrm{HAuCl}_{4} \cdot 3 \mathrm{H}_{2} \mathrm{O}\right.$ ) was obtained from Acros Organics (Thermo Fischer Scientific, USA). All chemicals were analytical grade. Stock solutions of $\mathrm{HQ}(0.01$ $\mathrm{M})$ and $\mathrm{CC}(0.01 \mathrm{M})$ were freshly prepared.

\section{Apparatus}

Electrochemical measurement experiments were conducted with an AUTOLAB PGSTAT 302N electrochemical workstation with Nova 11.1 software (Eco Chemie, The Netherlands). A conventional three-electrode system consisting of a platinum wire as auxiliary electrode a silver/silver chloride $(\mathrm{Ag} / \mathrm{AgCl})$ as reference electrode and a bare or modified glassy carbon electrode as working electrode $(d=3 \mathrm{~mm})$, was used. The surface characterization of the modified electrode was performed using a scanning electron microscope (SEM, FEI Nova NanoSEM 650 microscope (The Netherlands)). All measurements were performed at room temperature.

\section{Preparation of the Electrochemical Sensor}

Firstly, the GC electrode was carefully polished with $0.05 \mu \mathrm{mol} \mathrm{L-1}$ alumina slurry and then washed thoroughly with ethanol and ultrapure water. Then, sonication purifying was used to remove the alumina residues. The AuNP were electrodeposited on the surface of the GCE with a $0.6 \mathrm{mmol}$ $\mathrm{L}^{-1} \mathrm{HAuCl}_{4}$ solution in $0.5 \mathrm{M} \mathrm{H}_{2} \mathrm{SO}_{4}$ for 15 cycles in the potential range from 0.2 to $+1.2 \mathrm{~V}$ at a scan rate of $100 \mathrm{mVs}^{1}$ [18]. The $\mathrm{P}(\mathrm{AG})$ film was electrodeposited on the surface of the GCE/AuNP electrode by the $\mathrm{CV}$ method in $2.5 \mathrm{mmol} \mathrm{L}^{-1} \mathrm{~L}$-arginine (0.1 mol L-1 PBS, $\mathrm{pH}$ 7.0) solution between $-2.5 \mathrm{~V}$ and $+2.3 \mathrm{~V}$ at a scan rate of $100 \mathrm{mVs}^{-1}$ for 7 cycles [19]. After electropolymerization, the composite electrode was washed with ultrapure water and then air-dried. For comparison, the AuNP/GCE and $P(A G) / G C E$ were also prepared under the same condition. 

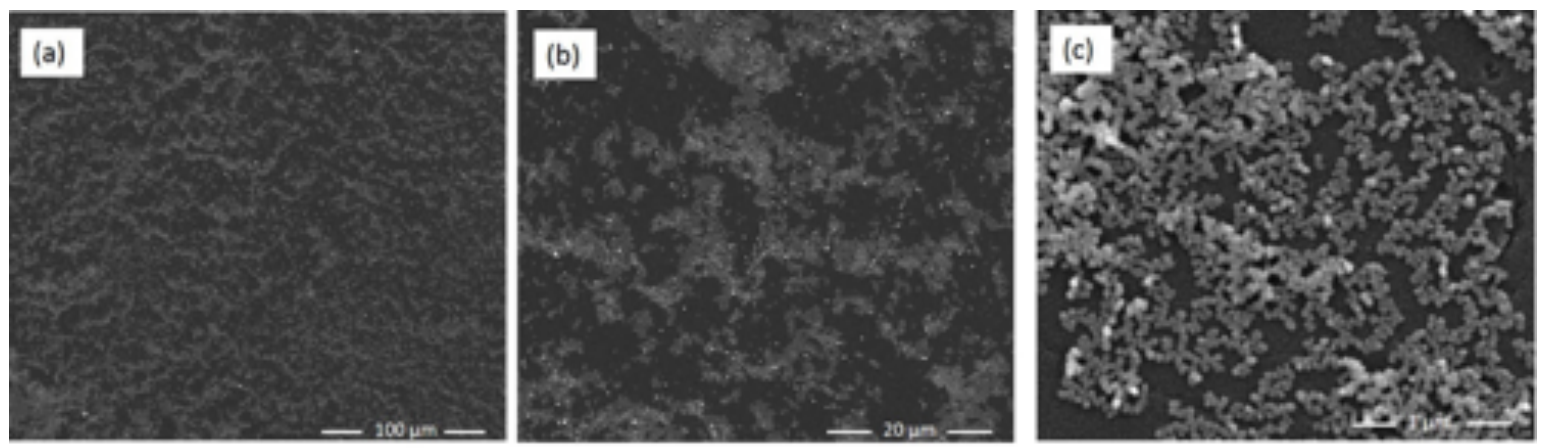

Figure 1. SEM image of $P(A G) / A U N P / G C E$ electrode at different magnifications.

\section{RESULTS AND DISCUSSION}

\section{SEM Images of $P(A G) / A u N P / G C E$}

To investigate the morphology of $P(A G) / A U N P / G C E$, the scanning electron micrographs were taken. Figure 1 depicts that the $P(A G) / A u N P / G C E$ is electrodeposited onto the surface of GCE and exhibits a porous structure (Figure 1). When the image was further magnified, white dots are clearly seen in $\mathrm{Fi}$ gure $1 \mathrm{c}$ that indicates the presence of AuNP. These nanostructures were covered with the $P(A G)$ thin film indicating that the $P(A G) / A u N P$ composite was successfully obtained on the GCE by the CV technique.

\section{Electrochemical Characteristics of Modified Electrodes}

Electrochemical characterictis of the bare and the modified electrodes were performed by CV measurements. Figure $2 \mathrm{~A}$ exhibits the CVS of BGCE and modified electrodes in $0.1 \mathrm{~mol} \mathrm{~L}^{-1} \mathrm{KCl}$ containing 5.0 mmol $\mathrm{L}^{-1}$ ferro-ferricyanide $\left(\mathrm{Fe}(\mathrm{CN})_{6}^{3 / 4}\right.$ ) redox $\mathrm{CO}^{-}$ uple (1:1). A pair of well-separated redox peaks with the lowest anodic and cathodic peak currents was observed at the BGCE (curve a) and peak-peak separation $\left(\Delta \mathrm{E}_{\mathrm{p}}\right)$ was estimated as $312 \mathrm{mV}$. Then, the surface of the electrode was modified with AuNP (curve b) or P(AG) (curve c). The anodic and cathodic peak currents both increased and $\Delta \mathrm{E}_{\mathrm{p}}$ decreased, which indicated that AuNP and $P(A G)$ can enhance the electron transfer reaction between the electrode surface and the redox probe solution. When the AuNP were combined with the $P(A G)$, the $P(A G) / A u N P / G C E$ exhibited the highest redox peak currents and the value of the $\Delta \mathrm{E}_{\mathrm{p}}$ negligibly changed to $115 \mathrm{mV}$. This result might be attributed to the contribution of the AuNP to the electron transfer reaction [20].
The electrochemical impedance properties of the bare and modified electrodes were recorded in redox probe solution. The Nyquist plots for impedance measurements are given in Figure $2 \mathrm{~B}$. Obviously, the BGCE showed a large semicircle, indicating the lowest rate for electron transfer. The AuNP/GCE (curve b) and P(AG)/GCE (curve c) showed smaller electron resistance value $\left(R_{\text {et }}\right)$ compared with the BGCE. It indicates that the presence of AuNP or P(AG) could greatly increase the electron transfer reaction. Moreover, the smallest $R_{\text {et }}$ was observed at the $P(A G) / A u N P / G C E$. This effect can be attributed to the synergistic effect between AuNP and $P(A G)$.

\section{Electrochemical Behaviour of $\mathrm{HQ}$ and $\mathrm{CC}$ at Modified GCEs}

The electrochemical behaviour of $\mathrm{HQ}$ and $\mathrm{CC}$ at the bare and the modified electrodes was studied by CV. Figure 3 presents the cyclic voltammograms of the bare GCE and different electrodes containing a mixture of $50.0 \mu \mathrm{mol} \mathrm{L} \mathrm{L}^{-1} \mathrm{HQ}$ and $50.0 \mu \mathrm{mol}$ $\mathrm{L}^{-1} \mathrm{CC}$ in $0.1 \mathrm{M}$ PBS ( $\mathrm{pH} 7.0$ ) in the potential range of -0.2 to $+0.4 \mathrm{~V}$. As seen in Figure $3 \mathrm{a}$, a broad peak was observed due to the overlapping oxidation peaks of $H Q$ and CC. However, the P(AG)/AuNP/ GCE separated the voltammetric peaks into two well-separated peaks at the potentials of 0.044 $\mathrm{V}(\mathrm{HQ})$ and $0.151 \mathrm{~V}(\mathrm{CC})$. For the GCE/AuNP/P(AG) (curve d) an obvious increase in each peak current was obtained when compared with those of the AuNP/GCE (curve b) and P(AG)/GCE (curve c). The excellent electrochemical performance of the modified electrode could be ascribed to the large surface area, good electronic conductivity and synergistic effects between the AuNP and P(AG) which would be beneficial for improved electron transfer kinetics. The distinguished separation of 

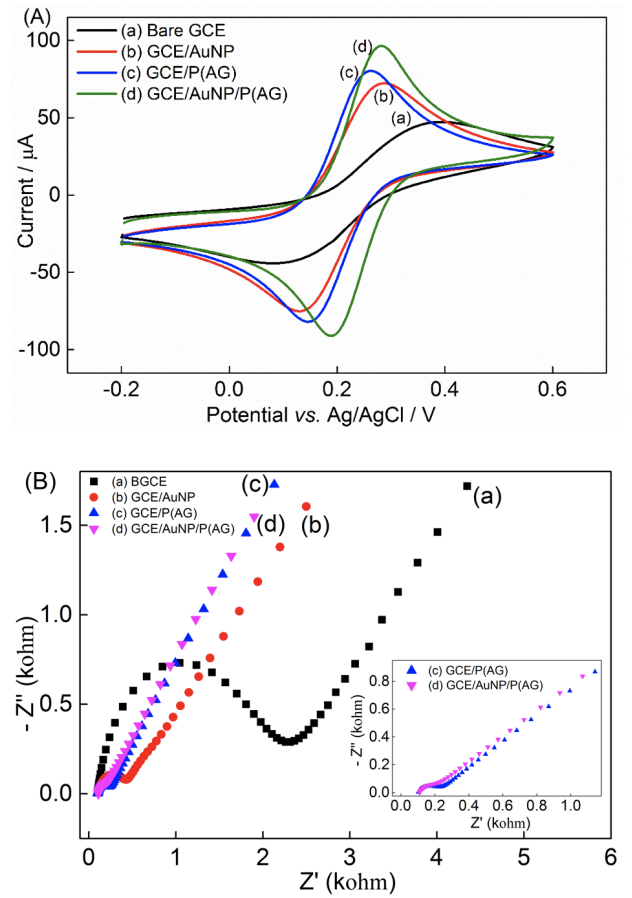

Figure 2. (A) Cyclic voltammograms and (B) the Nyquist plots of of the BGCE (a), AuNP/GCE (b), P(AG)/GCE (c) and $P(A G) / A U N P / G C E(d)$ at the scan rate of $50 \mathrm{mV} \mathrm{s}^{1}$ in $0.1 \mathrm{M} \mathrm{KCl}$ containing $5.0 \mathrm{mM} \mathrm{Fe}(\mathrm{CN})_{6}^{3 / 4}$.

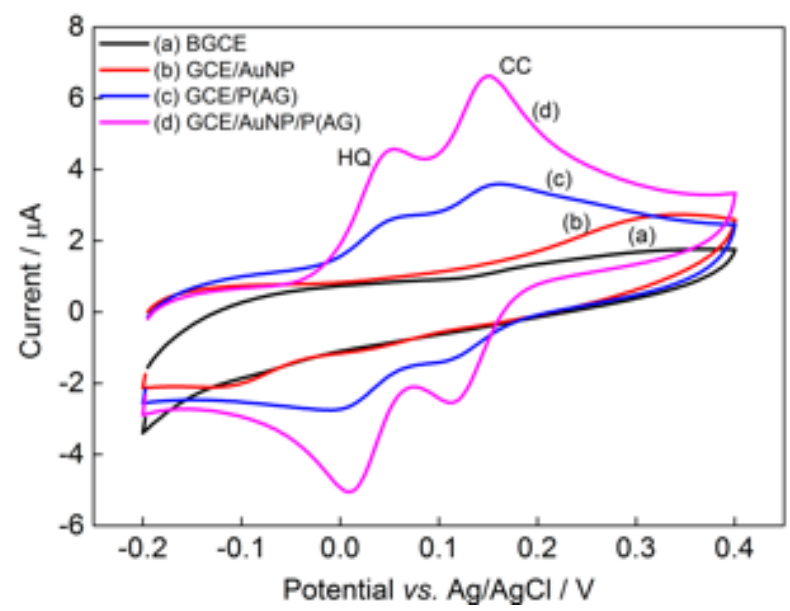

Figure 3. Cyclic voltammogram of the bare GCE (a), AuNP/GCE (b), $P(A G) / G C E(C)$ and $P(A G) / A u N P / G C E(d)$ in $0.1 \mathrm{~mol} \mathrm{~L}^{-1} P B S(p H$ 7.0) containing $50.0 \mu \mathrm{mol} \mathrm{L}^{-1} \mathrm{HQ}$ and $50.0 \mu \mathrm{mol} \mathrm{L}^{-1} \mathrm{CC}$. Scan rate: $50 \mathrm{mV} \mathrm{s}^{1}$.

the oxidation peak potentials and the increased peak currents suggests that the simultaneous determination of $\mathrm{HQ}$ and $\mathrm{CC}$ in a mixture solution is applicable.

\section{Effect of Solution pH}

The effect of $\mathrm{pH}$ on the voltammetric response of the $P(A G) / A u N P / G C E$ was performed in the $\mathrm{pH}$ range 5.0-8.0. As shown in Figure $4 \mathrm{~A}$, the $E_{\mathrm{pa}}$ values shifted negatively with increasing $\mathrm{pH}$ from
5.0 to 8.0 for both $\mathrm{HQ}$ and CC. In addition, peak potential of $\mathrm{HQ}$ and $\mathrm{CC}$ were proportional to the $\mathrm{pH}$ value. The linear regression equations for $E_{\mathrm{pa}}$ with the $\mathrm{pH}$ for $\mathrm{HQ}$ and $\mathrm{CC}$ were $E_{\mathrm{pa}}=614.08 \mathrm{pH}$ $91.52\left(R^{2}=0.995\right)$ and $E_{\mathrm{pa}}=635.49 \mathrm{pH} 95.36$ $\left(R^{2}=0.995\right)$, respectively. The slopes are very close to the theoretical data of $59.2 \mathrm{mV} \mathrm{pH}^{1}$ for equal number of proton and electron process [8]. Furthermore, the oxidation peak currents of $\mathrm{HQ}$ and $\mathrm{CC}$ increased with increasing $\mathrm{pH}$ from 5.0 to 

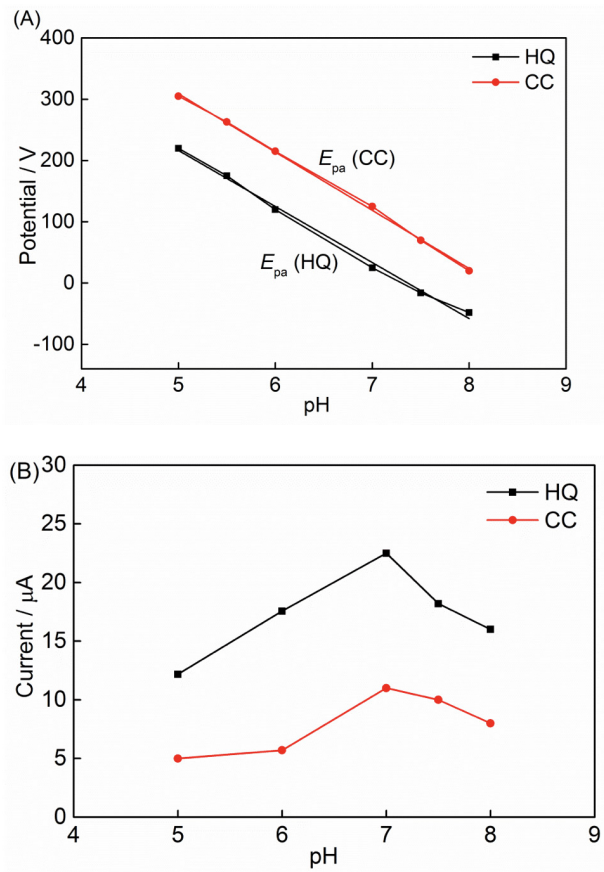

Figure 4. Effect of $\mathrm{pH}$ on (A) DPV peak potential and (B) DPV peak current for the oxidation of $50.0 \mu \mathrm{mol} \mathrm{L}^{-1} \mathrm{HQ}$ and 50.0 $\mu \mathrm{mol} \mathrm{L} \mathrm{L}^{-1} \mathrm{CC}$.

7.0 and then decreased quickly (Figure 4B). Thus, $\mathrm{pH} 7.0$ was selected as optimum $\mathrm{pH}$ for the analysis of $\mathrm{HQ}$ and $\mathrm{CC}$ simultaneously.

\section{Effect of Scan Rate}

The influence of the scan rate of the potential sweep on the peak current of $H Q$ and $C C$ was studied at the $P(A G) / A u N P / G C E$. Figure $5(A)$ and (C) show the cyclic voltammograms at the $P(A G) /$ AuNP/GCE electrode. The peak currents increased with increasing scan rate. As shown in Figure $4(B, D)$, good linear relationships were obtained between the oxidation peak current and the scan rate for $\mathrm{HQ}$ and $\mathrm{CC}$ with the linear equations (inset of Figure $5(B)$ and (D)). This confirms that the electron transfer reactions for $\mathrm{HQ}$ and $\mathrm{CC}$ were adsorption-controlled processes [21,22].

\section{Individual and Simultaneous Determination of $\mathrm{HQ}$ and $\mathrm{CC}$}

The relationship between the concentration of $\mathrm{HQ}$ and $\mathrm{CC}$ and the peak currents was investigated by differential pulse voltammetry. In these measurements, the concentration of one compound was changed while the other one was kept constant. As seen in Figure $5(A)$ and (B), the peak currents of $\mathrm{HQ}$ and $\mathrm{CC}$ linearly increased in the concentration ranges of $5.0600 \mu \mathrm{mol} \mathrm{L}^{-1}, 5.0 \quad 600$ $\mu \mathrm{mol} \mathrm{L}^{-1}$, respectively. The linear fitting regression equations were $I_{\text {pa }}(\mu \mathrm{A})=0.262 \mathrm{c}\left(\mu \mathrm{mol} \mathrm{L^{-1 }}\right)+0.475$ $\left(R^{2}=0.986\right)$ for $\mathrm{HQ}$ and $l_{\mathrm{pa}}(\mu \mathrm{A})=0.02 \mathrm{c}\left(\mu \mathrm{mol} \mathrm{L}^{-1}\right)+$ $0.083\left(R^{2}=0.996\right)$ for $C$ C. The detection limits for $\mathrm{HQ}$ and $\mathrm{CC}$ were $1.5 \mu \mathrm{mol} \mathrm{L}^{-1}$ and $1.42 \mu \mathrm{mol} \mathrm{L}^{-1}$, respectively $(3 \mathrm{~s} / \mathrm{m})$.

The comparative results between the $P(A G) /$ AuNP/GCE with other modified electrodes was summarized in Table 1. The obtained results values were comparable with those previously reported in studies using different types of electrodes.

Figure $6 \mathrm{~A}$ depicts the DPV curves for the detection of $H Q$ and $C C$ in a mixture solution while their concentration changed simultaneously. The results show two well-defined anodic peaks for $\mathrm{HQ}$ and $\mathrm{CC}$ increased with peak potentials. Figure $6 \mathrm{~B}$ and $(C)$ show the increase in peak currents with the concentrations of $\mathrm{HQ}$ and $\mathrm{CC}$.

\section{Repeatability, Reproducibility and Selectivity of the Prepared Sensor}

To evaluate the repeatability of the sensor, differential pulse voltammograms were measured five times repetitively in PBS ( $\mathrm{pH} 7.0)$ containing $50 \mu \mathrm{mol} \mathrm{L} \mathrm{L}^{-1} \mathrm{HQ}$ and $\mathrm{CC}$. The relative standard deviations (RSD) are $2.37 \%$ and $3.26 \%$, respectively showing that the $P(A G) / A U N P / G C E$ has good re- 

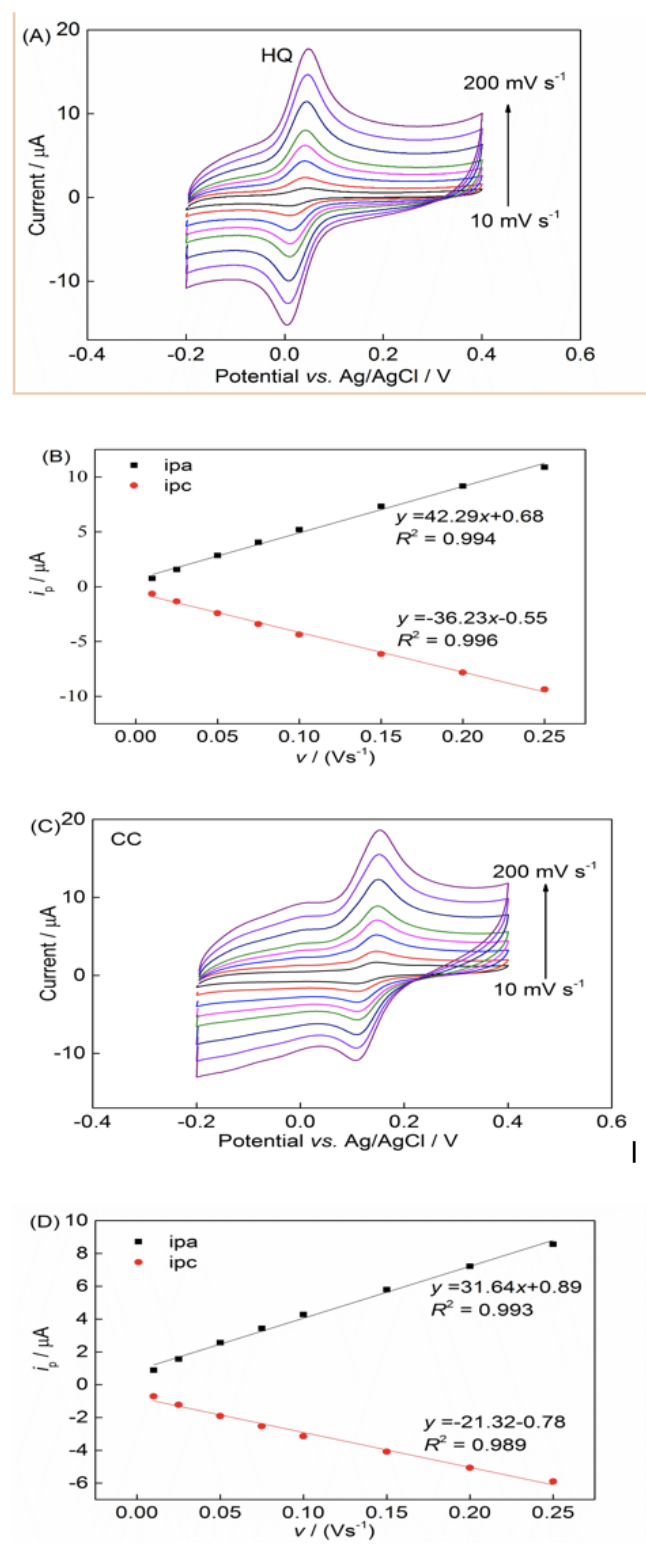

Figure 5. CV curves of $50.0 \mu \mathrm{mol} \mathrm{L} \mathrm{L}^{-1} \mathrm{HQ}(\mathrm{A})$ and $50.0 \mu \mathrm{mol} \mathrm{L} \mathrm{L}^{-1} \mathrm{CC}(\mathrm{C})$ in PBS $\left(0.1 \mathrm{~mol} \mathrm{~L}^{-1}, \mathrm{pH}\right.$ 7.0) at the P(AG)/AuNP/GCE electrode with various scan rate between $10200 \mathrm{mVs} 1$, and the corresponding plots of peak current versus scan rate $(B, D)$.

peatability. In addition, the reproducibility was evaluated using five different electrodes, which were constructed independently. The RSDs were $4.22 \%$ and $5.18 \%$ for the peak measuring in 50 $\mu \mathrm{mol} \mathrm{L}^{-1} \quad \mathrm{HQ}$ and $\mathrm{CC}$ which confirm the reliability of the fabrication process.

The effects of various substances such as ascorbic acid, dopamine, urea and phenol were investigated by DPV. Differential pulse voltammograms were recorded for $50 \mu \mathrm{mol} \mathrm{L}^{-1} \mathrm{HQ}$ and CC in the presence of $50 \mu \mathrm{mol} \mathrm{L}^{-1}$ each of these sub- stances. It is found that ascorbic acid, dopamine, urea and phenol did not cause any interfering effect on the voltammetric signals of the $\mathrm{HQ}$ and $\mathrm{CC}$ at the $P(A G) / A u N P / G C E$ surface. It shows that the proposed sensor has good anti-interference ability towards the electro-oxidation of $\mathrm{HQ}$ and $\mathrm{CC}$.

\section{Analysis of Real Samples}

The analytical applicability of the proposed method was investigated in local tap water samples at the $P(A G) / A u N P / G C E$. The amounts of $H Q$ and $C C$ in the samples were determined by DPV techni- 

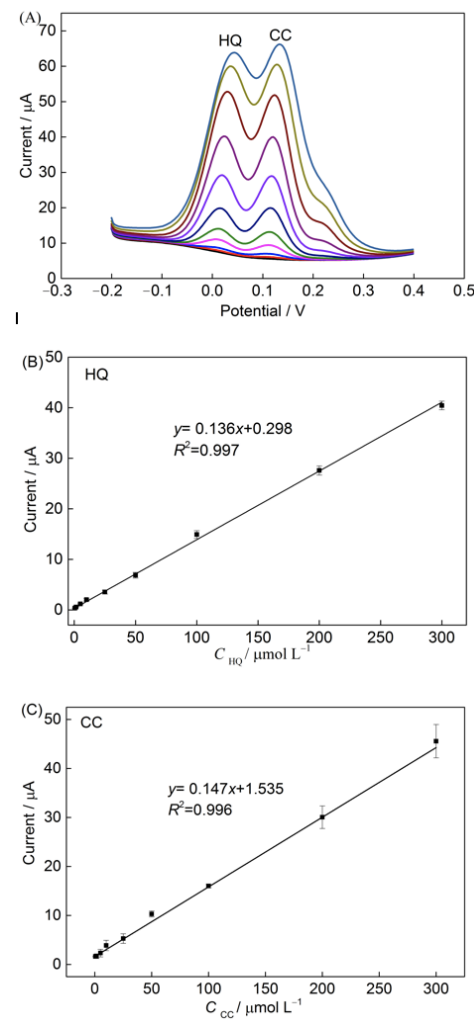

Figure 6. $\mathrm{CV}$ curves of $50.0 \mu \mathrm{mol} \mathrm{L-1} \mathrm{HQ}(\mathrm{A})$ and $50.0 \mu \mathrm{mol} \mathrm{L} \mathrm{L}^{-1} \mathrm{CC}(\mathrm{C})$ in $\mathrm{PBS}\left(0.1 \mathrm{~mol} \mathrm{~L}^{-1}, \mathrm{pH} 7.0\right)$ at the $\mathrm{P}(\mathrm{AG}) / \mathrm{AuNP} / \mathrm{GCE}$ electrode with various scan rate between $10200 \mathrm{mVs} 1$, and the corresponding plots of peak current versus scan rate (B, D).

Table 1. A comparison table of different modified electrodes for the simultaneous analysis of $H Q$ and CC.

\begin{tabular}{|c|c|c|c|c|c|}
\hline \multirow{2}{*}{ Electrode } & \multicolumn{2}{|c|}{ Linear range $\left(\mu \mathrm{mol} \mathrm{L}^{-1}\right)$} & \multicolumn{2}{|c|}{ Detection limit $\left(\mu \mathrm{mol} \mathrm{L}{ }^{-1}\right)$} & \multirow[b]{2}{*}{ Reference } \\
\hline & $\mathrm{HQ}$ & $\mathrm{CC}$ & $\mathrm{HQ}$ & $\mathrm{CC}$ & \\
\hline RGO/MWCNT/GCE & 8.0391 .0 & 5.5540 .0 & 2.6 & 1.8 & [23] \\
\hline GR-La(OH)3/GCE & 5.0300 .0 & 5.0300 .0 & 0.015 & 0.01 & [7] \\
\hline Pyridine-NG & 5.0200 .0 & 5.0200 .0 & 0.38 & 1.0 & [24] \\
\hline CMK-3/GCE & 10.0200 .0 & 10.0300 .0 & 0.076 & 0.1 & [25] \\
\hline MWCNT/PASA//GCE & 6.0400 .0 & 6.0700 .0 & 1.0 & 1.0 & [26] \\
\hline $\mathrm{MnO}_{2} / \mathrm{Pt} / \mathrm{GCE}$ & 3.0481 .0 & 15.0447 .0 & - & - & [6] \\
\hline$P(A G) / A u N p / G C E$ & 5.0600 .0 & 5.0600 .0 & 1.5 & 1.42 & This work \\
\hline
\end{tabular}

glassy carbon electrode (GCE),

reduced graphene oxide (RGO),

multi-walled carbon nanotube (MWCNT),

graphene (GR),

lanthanum hydroxide $\left(\mathrm{La}(\mathrm{OH})_{3}\right)$,

nitrogen doped graphene (NG),

mesoporous carbon material CMK-3 (CMK-3),

poly(amidosulfonic acid) (PASA),

platinum (Pt),

manganese dioxide $\left(\mathrm{MnO}_{2}\right)$. 
Table 2. Simultaneous determination of $\mathrm{HQ}$ and $\mathrm{CC}$ in tap water samples $(\mathrm{n}=3)$.

\begin{tabular}{lllllll}
\hline & \multicolumn{2}{l}{ Added $\left(\mu \mathrm{mol} \mathrm{L}^{-1}\right)$} & \multicolumn{2}{l}{ Found $\left(\mu \mathrm{mol} \mathrm{L}^{-1}\right)$} & \multicolumn{2}{l}{ Recovery $(\%)$} \\
\hline Sample no & HQ & CC & HQ & CC & HQ & CC \\
\hline 1 & 20 & 80 & 18.92 & 81.26 & 94.60 & 101.57 \\
\hline 2 & 40 & 40 & 41.22 & 42.53 & 103.05 & 106.32 \\
\hline 3 & 80 & 20 & 82.18 & 19.26 & 102.72 & 96.30 \\
\hline
\end{tabular}

que. The results, which were calculated from the related calibration plot, are shown in Table 2 . The recovery values were $94.60 \%-103.05 \%$ for $\mathrm{HQ}$ and 96.30-106.32 for CC, demonstrating the applicability of the developed method.

\section{Conclusion}

In summary, a sensitive method for $\mathrm{HQ}$ and $\mathrm{CC}$ determination was proposed by fabricating $P(A G)$ and AUNP modified GCE. The modified electrode was characterized by the CV, EIS and SEM. The developed sensor has the ability to separate oxidation signals of $\mathrm{HQ}$ and $\mathrm{CC}$ with low LOD values and wide linear working ranges. In addition, the sensor shows high selectivity, reproducibility and repeatability towards $\mathrm{HQ}$ and $\mathrm{CC}$ detection. The prepared sensor was utilized to determine $\mathrm{HQ}$ and $\mathrm{CC}$ in real samples and high recovery values were obtained.

\section{References}

1. T. Gan, J. Sun, K. Huang, L. Song, Y. Li, A graphene oxide-mesoporous $\mathrm{MnO}_{2}$ nanocomposite modified glassy carbon electrode as a novel and efficient voltammetric sensor for simultaneous determination of hydroquinone and catechol, Sens. Actuat. B: Chem. 177 (2013) 412-418.

2. Y. Wang, J. Qu, S. Li, Y. Dong, J. Qu, Simultaneous determination of hydroquinone and catechol using a glassy carbon electrode modified with gold nanoparticles, ZnS/NiS@ZnS quantum dots and L-cysteine, Microchim. Acta, 182 (2015) 2277-2283.

3. P. Nagaraja, R.A. Vasantha, K.R. Sunitha, A sensitive and selective spectrophotometric estimation of catechol derivatives in pharmaceutical preparations, Talanta, 55 (2001) 1039-1046.

4. G. Marrubini, E. Calleri, T. Coccini, A.F. Castoldi, L. Manzo, Direct Analysis of Phenol, Catechol and Hydroquinone in Human Urine by Coupled-Column HPLC with Fluorimetric Detection, Chromatographia, 62 (2005) 25-31.
5. M.F. Pistonesi, M.S. Di Nezio, M.E. Centurión, M.E. Palomeque, A.G. Lista, B.S. Fernández Band, Determination of phenol, resorcinol and hydroquinone in air samples by synchronous fluorescence using partial least-squares (PLS), Talanta, 69 (2006) 12651268.

6. B. Unnikrishnan, P.-L. Ru, S.-M. Chen, Electrochemically synthesized $\mathrm{Pt}-\mathrm{MnO}_{2}$ composite particles for simultaneous determination of catechol and hydroquinone, Sens. Actuat. B: Chem., 169 (2012) 235-242.

7. Z. Guo, Y. Lu, J. Li, X.-f. Xu, G.-q. Huang, Z.-y. Wang, Simultaneous determination of hydroquinone and catechol using an electrode modified by a composite of graphene/lanthanum hydroxide nanowires, Anal. Methods, 6 (2014) 8314-8320.

8. W. Si, W. Lei, Y. Zhang, M. Xia, F. Wang, Q. Hao, Electrodeposition of graphene oxide doped poly(3,4ethylenedioxythiophene) film and its electrochemical sensing of catechol and hydroquinone, Electrochim. Acta, 85 (2012) 295-301.

9. D.P. Santos, M.F. Bergamini, A.G. Fogg, M.V.B. Zanoni, Application of a Glassy Carbon Electrode Modified with Poly (Glutamic Acid) in Caffeic Acid Determination, Microchim. Acta, 151 (2005) 127-134.

10. K. Zhang, P. Luo, J. Wu, W. Wang, B. Ye, Highly sensitive determination of Sunset Yellow in drink using a poly (I-cysteine) modified glassy carbon electrode, Anal. Methods, 5 (2013) 5044-5050.

11. Z. Guo, G.-q. Huang, J. Li, Z.-y. Wang, X.-f. Xu, Graphene oxide-Ag/poly-l-lysine modified glassy carbon electrode as an electrochemical sensor for the determination of dopamine in the presence of ascorbic acid, J. Electroanal. Chem., 759, Part 2 (2015) 113-121.

12. Y. Yi, G. Zhu, X. Wu, K. Wang, Highly sensitive and simultaneous electrochemical determination of 2-aminophenol and 4-aminophenol based on poly(l-arginine)- $\beta$-cyclodextrin/carbon nanotubes@ graphene nanoribbons modified electrode, Biosens. and Bioelectron., 77 (2016) 353-358.

13. G. Zhang, P. He, W. Feng, S. Ding, J. Chen, L. Li, H. He, S. Zhang, F. Dong, Carbon nanohorns/poly(glycine) modified glassy carbon electrode: Preparation, characterization and simultaneous electrochemical determination of uric acid, dopamine and ascorbic acid, J. Electroanal. Chem., 760 (2016) 24-31.

14. F. Zhang, S. Gu, Y. Ding, L. Zhou, Z. Zhang, L. Li, Electrooxidation and determination of cefotaxime on Au nanoparticles/poly (L-arginine) modified carbon paste electrode, J. Electroanal. Chem., 698 (2013) 25-30. 

15. Y. Li, Z. Ye, J. Zhou, J. Liu, G. Song, K. Zhang, B. Ye, A new voltammetric sensor based on poly(L-arginine)/ graphene-Nafion composite film modified electrode for sensitive determination of Terbutaline sulfate, J. Electroanal. Chem., 687 (2012) 51-57.

16. J. Du, R. Yue, F. Ren, Z. Yao, F. Jiang, P. Yang, Y. $\mathrm{Du}$, Simultaneous determination of uric acid and dopamine using a carbon fiber electrode modified by layer-by-layer assembly of graphene and gold nanoparticles, Gold Bullet., 46 (2013) 137-144.

17. F. Cui, X. Zhang, Electrochemical sensor for epinephrine based on a glassy carbon electrode modified with graphene/gold nanocomposites, J. Electroanal. Chem., 669 (2012) 35-41.

18. R.-S. Saberi, S. Shahrokhian, G. Marrazza, Amplified Electrochemical DNA Sensor Based on Polyaniline Film and Gold Nanoparticles, Electroanalysis, 25 (2013) 1373-1380.

19. F. Zhang, Z. Wang, Y. Zhang, Z. Zheng, C. Wang, Y. Du, W. Ye, Simultaneous electrochemical determination of uric acid, xanthine and hypoxanthine based on poly(l-arginine)/graphene composite film modified electrode, Talanta, 93 (2012) 320-325.

20. S. Zhao, K. Zhang, Y. Bai, W. Yang, C. Sun, Glucose oxidase/colloidal gold nanoparticles immobilized in Nafion film on glassy carbon electrode: Direct electron transfer and electrocatalysis, Bioelectrochem., 69 (2006) 158-163.

21. S. Erogul, S.Z. Bas, M. Ozmen, S. Yildiz, A new electrochemical sensor based on Fe304 functionalized graphene oxide-gold nanoparticle composite film for simultaneous determination of catechol and hydroquinone, Electrochim. Acta, 186 (2015) 302-313.
22. H. Yin, Q. Zhang, Y. Zhou, Q. Ma, T. liu, L. Zhu, S. Ai, Electrochemical behavior of catechol, resorcinol and hydroquinone at graphene-chitosan composite film modified glassy carbon electrode and their simultaneous determination in water samples, Electrochim. Acta, 56 (2011) 2748-2753

23. F. Hu, S. Chen, C. Wang, R. Yuan, D. Yuan, C. Wang, Study on the application of reduced graphene oxide and multiwall carbon nanotubes hybrid materials for simultaneous determination of catechol, hydroquinone, p-cresol and nitrite, Anal. Chim. Acta, 724 (2012) 40-46.

24. H.-L. Guo, S. Peng, J.-H. Xu, Y.-Q. Zhao, X. Kang, Highly stable pyridinic nitrogen doped graphene modified electrode in simultaneous determination of hydroquinone and catechol, Sens. Actuat. B: Chem., 193 (2014) 623-629.

25. J. Yu, W. Du, F. Zhao, B. Zeng, High sensitive simultaneous determination of catechol and hydroquinone at mesoporous carbon CMK-3 electrode in comparison with multi-walled carbon nanotubes and Vulcan XC-72 carbon electrodes, Electrochim. Acta, 54 (2009) 984-988.

26. D.-M. Zhao, X.-H. Zhang, L.-J. Feng, L. Jia, S.-F. Wang, Simultaneous determination of hydroquinone and catechol at PASA/MWNTs composite film modified glassy carbon electrode, Colloids Surf. B Biointerfaces, 74 (2009) 317-321. 